\title{
Transcript levels and translational control of hsp70 synthesis in Xenopus oocytes
}

\author{
Ann Horrell, John Shuttleworth, and Alan Colman \\ Department of Biological Sciences, University of Warwick, Coventry CV4 7AL, UK
}

\begin{abstract}
Until recently it was believed that Xenopus oocytes respond to heat shock by synthesizing the 70-kD heat shock protein hsp70 and that, uniquely amongst animal cell types, this response is mediated entirely at the translational level. This view has now been challenged and we present data that reevaluate the involvement of translational control in the heat shock response of Xenopus oocytes. RNase mapping shows that up to $13 \mathrm{pg}$ of hsp70A and hsp70B mRNA are accumulated by fully grown oocytes in the absence of heat shock. These transcripts are retained stably during maturation, fertilization, early cleavage, and following heat shock. However, no hsp70 protein synthesis can be detected by two-dimensional polyacrylamide gel analysis of ${ }^{35}$ S]methionine-labeled proteins from completely defolliculated oocytes, either before or during heat shock. Oocytes injected with hsp70A DNA rapidly accumulate high levels of hsp70 mRNA in their cytoplasm at normal temperature. During heat shock these oocytes accumulate more transcripts, but they remain in the nucleus and cytoplasmic levels remain constant. Translation of hsp70 from these transcripts is readily detectable at non-heat shock and heat shock temperatures. We conclude that (1) "exogenous" hsp70 transcripts are efficiently translated and not masked at normal temperatures in oocytes, and (2) oocytes are able to selectively translate hsp70 mRNA during heat shock.
\end{abstract}

[Key words: Xenopus; hsp70; mRNA levels, translational control]

Received April 4, 1987; revised version accepted May 7, 1987.

The ability to produce heat shock proteins (hsps) in response to increased temperature (together with a variety of other physiological stresses) is a property common to most, if not all, eukaryotic cells (Schlesinger et al. 1982; Pelham, 1985). Heat shock-induced expression of hsps has been well characterized, notably in Drosophila where regulation occurs at both the transcriptional and translational levels (Di Domenico et al. 1982; Hultmark et al. 1986). Induction involves the transient and coordinate activation of heat shock genes, through the binding of the heat shock transcription factor (HSTF) to highly conserved heat shock sequence elements (HSEs) in their promoter regions (Pelham 1982; Parker and Topol 1984). Rapidly accumulated hsp mRNA is then selectively translated at the elevated temperature while translation of most other cellular mRNAs is repressed (Storti et al. 1980|. The mechanisms underlying this translational selectivity remain unclear but are thought to involve (1) alterations in the efficiency of the translational apparatus of heat-shocked cells and (2) sequences present in the $5^{\prime}$ untranslated leader of hsp mRNA that facilitate preferential translation (Glover 1982; McGarry and Lindquist 1985; Hultmark et al. 1986).

Developmental and noncoordinate regulation of hsp gene expression has also been reported in a variety of nonstressed cells from Drosophila, yeast, human, and mouse (Zimmerman et al. 1983; Kurtz et al. 1986; Wu and Morimoto 1986; Bensaude et al. 1983). The presence of independent regulatory sequences, distinct from HSEs, in the promoter regions of several of these genes is providing some insight into their expression during normal cell growth and differentiation (Riddihough and Pelham 1986; Wu and Morimoto 1986). Recent studies on the developmental control of heat shock gene expression in Xenopus have indicated that alternative transcriptional and translational mechanisms may be utilized in oocytes. The hsp 70 genes are thought to be transcribed constitutively during oogenesis controlled by the activity of both HSE and CCAAT box regulatory elements in their promoters (Bienz 1984b, 1986). Significant amounts of hsp70 mRNA are accumulated but do not appear to be translated until the oocytes are heatshocked (Bienz and Gurdon 1982; Bienz 1984a). hsp70 synthesis by heat-shocked oocytes has therefore been attributed to translational activation followed by preferential translation of preexisting, masked hsp70 mRNA. In contrast, hsp 70 transcripts and hsp 70 synthesis have not been detected in unfertilized eggs or early embryos, facts that appear to correlate with their lack of thermotolerance (Bienz 1984a; Heikkila et al. 1985). Together these results imply that hsp 70 transcripts in oocytes contain features allowing them, first, to be masked at normal 
temperatures, second, to be preferentially translated during heat shock, and, third, to be selectively destroyed during maturation.

We became interested in hsp 70 expression during Xenopus oogenesis since it appeared to represent a novel example of translational control. However, recent evidence has suggested that the data on translation of hsp 70 by heat-shocked oocytes may be complicated by a contribution of protein derived from the several thousand follicle cells that initially surround each oocyte in the ovary. King and Davis (1987) could not detect hsp70 protein synthesis in defolliculated oocytes, and question the presence of hsp 70 mRNA in stage VI oocytes. To reinvestigate the phenomenon of translational activation of hsp70 mRNA we have used methods that ensure the complete removal of all follicle cells from the oocyte. Our initial studies have reevaluated the accumulation, stability, and fate of hsp70 mRNA in oocytes, eggs, and embryos. Using a sensitive RNase protection assay, we find that maternal hsp $70 \mathrm{~A}$ and hsp $70 \mathrm{~B}$ transcripts accumulate early in oogenesis. These transcripts are stable during heat shock in stage VI oocytes and, contrary to previous reports, persist in undiminished amounts in eggs and in stage 2, 8, and 11 embryos.

Using one- and two-dimensional polyacrylamide gel electrophoresis, we also fail to detect any hsp70 protein synthesis from the transcripts in defolliculated stage VI oocytes either before or during heat shock. This could be because the rate of hsp70 protein synthesis from endogenous transcripts is below the limit of detection of our analysis. We have therefore investigated an alternative strategy of expressing hsp70 protein from injected genes. We present here data on the accumulation and localization of hsp70A mRNA and its translation in oocytes. Translation of hsp70 protein is readily detectable at non-heat shock and heat shock temperatures in DNAinjected oocytes. These results will allow the design of experiments to investigate the structural features of hsp70 mRNA that facilitate preferential translation during heat shock.

\section{Results and discussion \\ Defolliculation procedure}

Xenopus oocytes are surrounded by two layers of somatic cells-an outer thecal layer containing blood vessels and fibroblasts, and an inner layer which on a stage VI oocyte (Dumont 1972) contains about $6000 \pm 1000$ follicle cells (see Materials and methods). To determine the relative contribution of hsp70 RNA and protein from the oocytes and these somatic cells (which we refer to simply as follicle cells), it was necessary to devise a method of completely defolliculating oocytes. We have tested a variety of different methods, but find that the following procedure is the quickest and most effective. Oocytes are given a brief collagenase treatment before removal of the thecal layer by manual dissection. After a second collagenase treatment, the oocytes are incubated in a hypertonic medium /see Materials and methods) in which the vitelline envelope becomes separated from the plasma membrane. This is then removed manually, together with the follicle cells embedded in it.

Removal of the somatic cells can be monitored by staining with Hoechst dye followed by visualization with a fluorescent microscope. This technique has the advantage that it does not require the sample to be fixed, so RNA and protein synthesis can be analyzed in the stained oocytes themselves, rather than in a parallel sample. Control experiments (not shown) show that the various procedures do not affect the recovery of radiolabeled proteins. Figure la shows an untreated (or folliculated) oocyte. The dark band in the center of the picture is a blood vessel. Nuclei in the thecal layer have a distinctive comma shape and are more sparsely distributed than those in the inner follicle layer. Removing the theca also removes variable numbers of cells from the inner layer (Fig. 1b). The remainder are embedded in the vitelline membrane and invariably removed with it (Fig. lc). Therefore, it is crucial to remove both the theca and

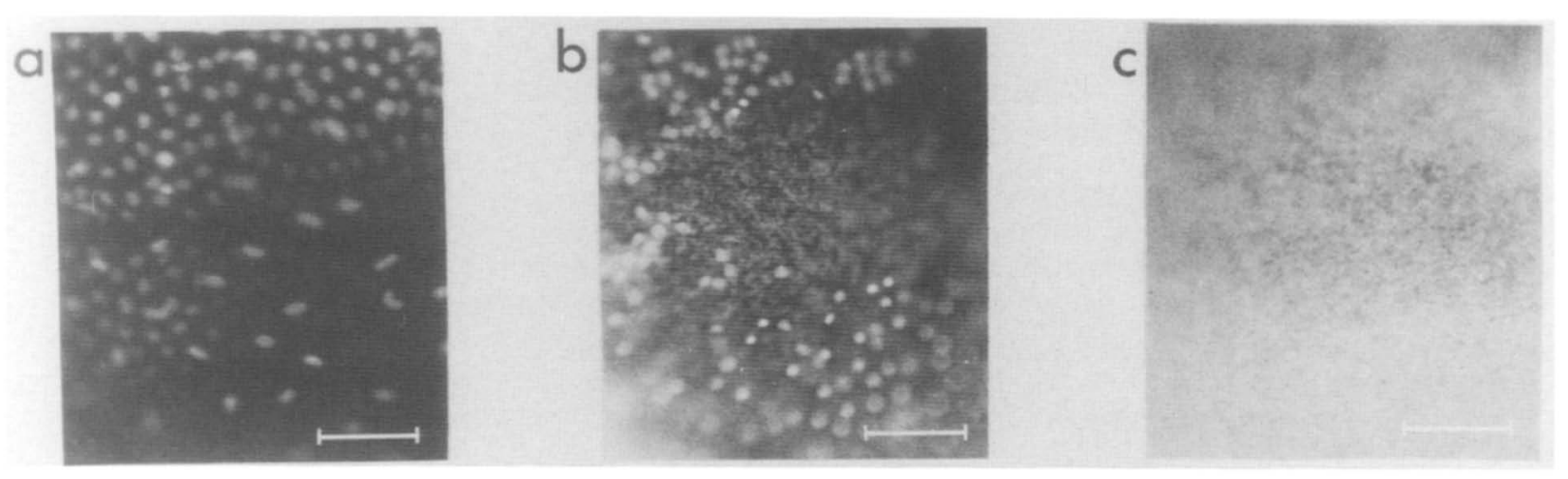

Figure 1. Oocytes at various stages of defolliculation, stained with Hoechst dye, and photographed under UV and visible light: $(a)$ a folliculated oocyte, $(b)$ an oocyte with islands of follicle cells remaining after removal of the theca, and $(c)$ a completely defolliculated oocyte. Scale bar, $10 \mu \mathrm{m}$. 
the vitelline membrane to ensure that no follicle cells are left attached to the occyte.

\section{Oogenic hsp70 mRNA levels}

The presence of significant amounts of hsp 70 mRNA in non-heat-shocked Xenopus oocytes is central to the proposition that hsp70 expression is mediated at the translational level, by mRNA recruitment or activation, in these cells. Xenopus laevis is known to possess several different hsp 70 genes but their relative levels of expression in oocytes is not known. The complete (hsp70A) and partial (hsp70B) sequence information that has been published for two of the genes shows considerable homology in the $5^{\prime}$ untranslated regions of the mRNA (Bienz 1984b). We have obtained additional sequence data for the hsp70B gene, extending from the AhaIII site -16 upstream of the cap site to the HindIII site at +471 in the coding region. Figure 2 shows that in addition to the single base changes already reported at positions $-13,-1,18,21$, and 46 the hsp $70 \mathrm{~B}$ leader sequence contains seven additional bases at positions 102 to 108 when compared with the published hsp $70 \mathrm{~A}$ sequence. This region of the hsp70B gene has been cloned into pGEM-1 and used to transcribe in vitro a 506-nucleotide anti-sense RNA probe using SP6 RNA polymerase ( 13 nucleotides from the AhallI site to the cap site, 476 nucleotides from the cap site to the end of the HindIII site, and 17 nucleotides of vector sequencel. When the probe is annealed to hsp 70B mRNA and digested with RNase, a 476-nucleotide protected fragment is generated (see Fig. 2). However, with hsp70A mRNA a shorter 368-nucleotide protected fragment is formed because of the deletion in its leader (see Fig. 2). This probe can therefore detect correctly initiated hsp $70 \mathrm{~B}$ transcripts and also distinguish the relative proportion of hsp70A and hsp70B transcripts in an RNase protection assay.

The relative levels of hsp70 mRNA present in stage VI oocytes, with and without attached follicle cells, both before and after a $2-\mathrm{hr}$ heat shock at $35^{\circ} \mathrm{C}$, are shown in Figure 3 . Non-heat-shocked oocytes clearly contain detectable levels of both hsp70A and hsp70B mRNA (Fig. 3 , lanes 1 and 3). The level of transcripts is identical in both folliculated and defolliculated oocytes at $20^{\circ} \mathrm{C}$ indicating that they are contained within the oocyte. The amount of hsp70 mRNA present has been estimated by titrating various amounts of synthetic sense hsp70 mRNA (from 2.5 to $5000 \mathrm{pg}$ ) in the RNase protection assay and comparing the counts eluted from the gel for each sample (data not shown). Up to $6 \times 10^{6}$ copies (10 $\mathrm{pg}$ ) of hsp70A and $2 \times 10^{6}$ copies $(3 \mathrm{pg})$ of hsp70B mRNA are present per oocyte. The values are similar to the $3 \times 10^{6}$ copies per oocyte quoted by Bienz (1984a). However, it should be noted that, curiously, we have found that both the absolute and relative amounts of hsp70A and hsp70B mRNA vary considerably between frogs for reasons which are not known (data not shown). In most experiments levels around 5- to 10-fold less are obtained, while in different frogs the oocyte expression of hsp70A mRNA may be greater or less than hsp70B
mRNA, an effect that is invariably paralleled in the accompanying follicle cells during heat shock.

Heat shock results in no detectable increase in hsp 70 mRNA within the oocyte (Fig. 3, lanes 3 and 4) while there is a dramatic increase in hsp 70 mRNA attributable to induction of follicle cell genes (Fig. 3, lanes 1 and 2). Up to $4.2 \times 10^{7}$ hsp $70 \mathrm{~A}$ and $3.4 \times 10^{7}$ hsp $70 \mathrm{~B}$ transcripts are synthesized per oocyte complement of follicle cells, nearly 10 -fold the level of transcripts present within the oocyte. This represents a transcription rate of $7 \times 10^{2}$ to $8 \times 10^{2}$ transcripts/gene per hour, assuming 6000 follicle cells/oocytes (see above) and, since Xenopus laevis is tetraploid, four hsp70A and four hsp70B genes/nucleus. Additional confirmation of the identity of the protected fragments in Figure 3 was obtained by independently injecting either hsp70A or hsp70B DNA into oocyte nuclei. The transcripts accumulated by injected oocytes were mapped and found to give rise to protected fragments identical in size to those indicated in Figure 3 (data not shown).

In addition to hsp70A- and hsp70B-derived protected fragments, there is a further band of around 80 nucleotides in length omitted from Figure 3 but indicated by $c$ in Figure 4. This RNase-protected fragment is derived from an mRNA present in defolliculated oocytes at $20^{\circ} \mathrm{C}$ whose levels are not affected by heat shock. This band is most likely derived from heat shock cognate gene transcripts (Craig et al. 1983) present within the oocyte. These are known to have considerable homology to hsp70 and are readily detected as a smaller $2.4-\mathrm{kb}$ band separate from the heat-inducible 2.6-kb hsp 70 mRNA on Northern blots of oocyte RNA using an hsp70B probe (data not shown).

\section{The stability of oocyte hsp70 transcripts}

The data shown in Figure 3 also demonstrate that hsp70 transcripts are not lost from the oocyte during the course of a single heat shock. If the heat shock-induced activation of hsp70 mRNA is reversible and repeatable within $48 \mathrm{hr}$ (Bienz and Gurdon 1982), this would require reutilization of existing transcripts and poses a key question relating to the stability of oocyte hsp 70 mRNA. During a conventional heat shock response, mediated at the transcriptional level, hsp transcripts are degraded during recovery from heat shock provided that sufficient functional hsp has accumulated (Di Domenico et al. 1982). The data in Figure 3, lanes 2 and 5, show that this behavior is demonstrated by the transcripts induced in the follicle cells, where $70 \%$ disappear in the 24 -hr recovery period. In contrast when oocytes are allowed to recover for $24 \mathrm{hr}$ at $20^{\circ} \mathrm{C}$ following a single heat shock, the oocyte levels of hsp70 mRNA are unaltered (Fig. 3, lanes 4 and 7). This latter observation does not take into account any contribution from transcription occurring after the time at which heat shock was reversed, but this would amount to very little when considering the oocyte's potential for replacing hsp70 transcripts during only a 24 -hr period. This implies that if translation of hsp70 by oocytes ceases after recovery 
Horrell et al.

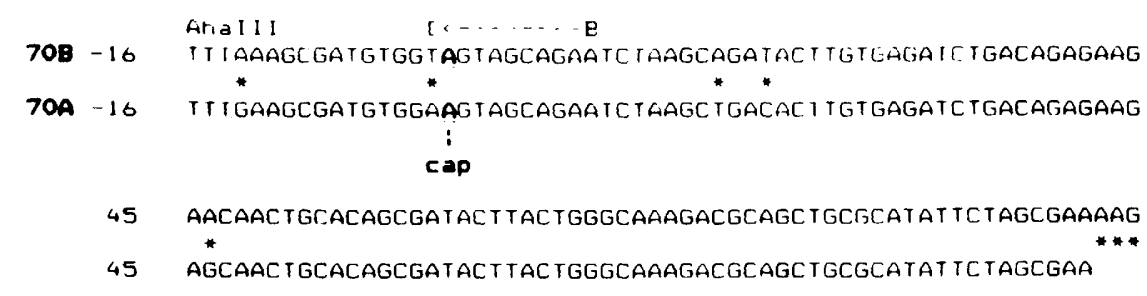

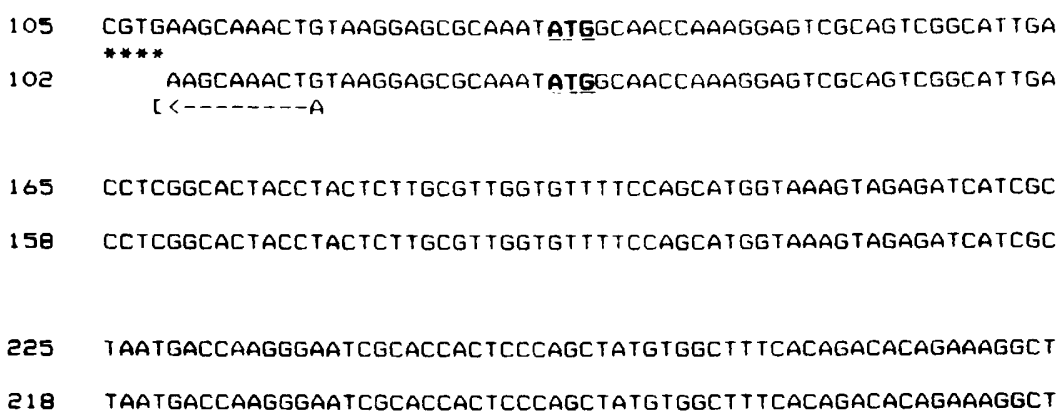

285 GATTGGCGATGCAGCCAAGAATCAAGTGGCCATGAACCCCCAGAATACAGTGTTTGATGC

278 GATTGGCGATGCAGCCAAGAATCAAGTGGCCATGAACCCCCAGAATACAGTGTTTGATGC

345 CAAGAGACTGATCGgGagaAAgtTCAATGATCCTGTAGTGCAgTGTGACTTGAAGCACTG

338 CAAGAGACTGATCGGGAGAAAGTTCAATGATCCTGTAGTGCAGTGTGACTTGAAGCACTG

405 GCCGTTCCAAGTGGTGAGCGATGAGgGGAAGCCTAAGgTCAAAGTGGAGTATAAAGGAGA

398 GCCGTTCCAAGTGGTGAGCGATGAGgGGAAGCCTAAGGTCAAAGTGGAGTATAAAGGAGA

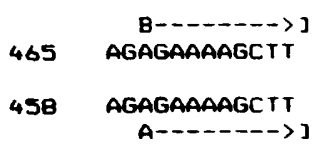

Figure 2. The $5^{\prime}$ leader sequences of hsp70A and hsp70B mRNA. The 484-bp Ahalli-HindIII fragment from the hsp70B subclone pXL16P (Bienz 1984b) was inserted into M13, mp18, and mpl9 and sequenced by dideoxynucleotide chain termination. The hsp70B sequence we obtained is compared with the published hsp70A sequence (Bienz 1984b). Mismatches are indicated by an asterisk (*). The hsp70A cap site, presumed hsp70B cap site, and first ATG codon for each sequence are underlined. The same AhaIII-HindIII fragment was subcloned in pGEM-1 and transcribed in vitro using SP6 RNA polymerase to produce a high-specific-activity anti-sense RNA probe. The $5^{\prime}$ and $3^{\prime}$ limits of probe protection are indicated for hsp70B transcripts $\|\leftarrow--B--\rightarrow\|$ and hsp $70 A$ transcripts $\{[\leftarrow--\mathbf{A}--\rightarrow \|$.

from heat shock, then existing hsp70 transcripts must be translationally rerepressed, as originally suggested by Bienz and Gurdon (1982).

The oogenic accumulation and fate of hsp70 transcripts

It has already been suggested that to accumulate several million transcripts in a stage VI oocyte, all hsp70 genes must be transcribed efficiently throughout most of oogenesis (Bienz and Gurdon 1982). This would also require hsp70 mRNA to be highly stable in the oocyte. By contrast the loss of hsp70 mRNA reported to occur during maturation (Bienz and Gurdon 1982) would necessitate destabilization of hsp70 mRNA. In view of the wide variation in oocyte hsp 70 mRNA levels (see above) and to examine these opposing effects on stability, hsp70 transcripts have been assayed in Dumont stages I-VI oocytes, unfertilized eggs, and stages 2,8 , and 11 embryos. Maximum hsp70 mRNA levels are accumulated by around stage III (see Fig. 4a). This suggests that either a steady-state rate of transcription and decay is reached at stage III or that the genes are no longer transcribed after stage III. Unfortunately, these alternatives are not readily distinguished experimentally. Golden et al. (1980) have reported a similar but not identical pattern of accumulation for several nonmitochondrial mRNAs, maximum levels being reached before vitellogenesis (i.e., during stage II).

Taking a figure of $6 \times 10^{6}$ transcripts/oocyte and a rate of 500-1000 transcripts/gene per hour, (see above), an oocyte would require up to 62 days to accumulate its 


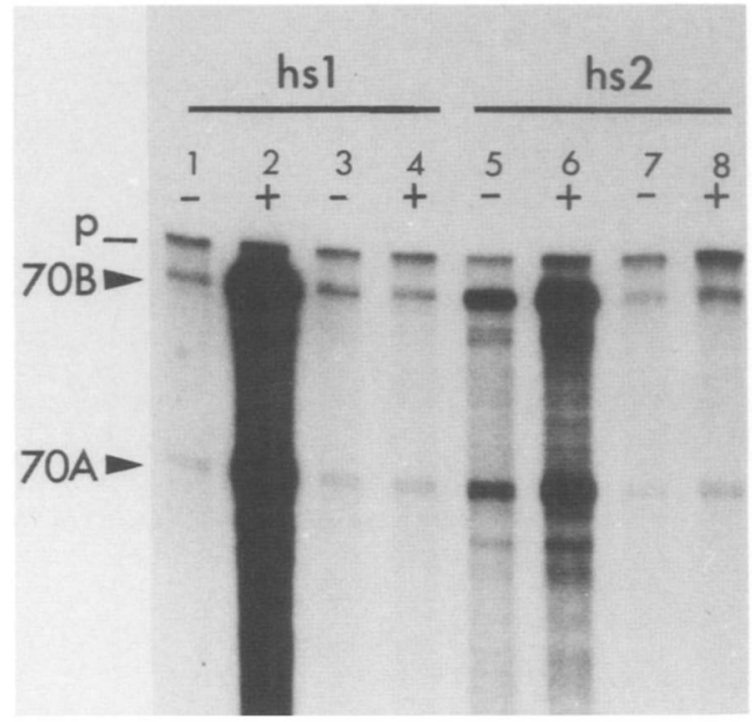

Figure 3. The stability of hsp70 transcripts following heat shock. The relative levels of hsp70A and hsp70B transcripts (indicated by arrows) were analyzed in folliculated (lanes 1 and 2) and defolliculated (lanes 3 and 4) oocytes both before $(-)$ and after $(+)$ a single heat shock at $35^{\circ} \mathrm{C}$ for $2 \mathrm{hr}(\mathrm{hsl})$ as described in Fig. 2. Heat-shocked oocytes were allowed to recover for 24 $\mathrm{hr}$ at $20^{\circ} \mathrm{C}$ and then the same analysis was performed on folliculated (lanes 5 and 6) and defolliculated (lanes 7 and 8) oocytes before $(-)$ and after $(+)$ a second heat shock at $35^{\circ} \mathrm{C}$ for $2 \mathrm{hr}$ (hs2). The RNA equivalent to one oocyte was analyzed in each case. Residual full-length probe is indicated $(p)$. hsp70 transcripts. There appears to be little agreement in the literature about the kinetics of oogenesis. However, a recent study by Callen et al. (1980) suggests a period of 2 years for production of mature oocytes in the first wave of oogenesis, stage III being achieved between 7 and 10 months after metamorphosis. This is clearly more than sufficient time to allow the accumulation of hsp70 mRNA. However, oogenesis is a highly discontinuous process and the ovary of a mature female contains oocytes arrested at various stages. A large proportion of the oocytes are arrested in late stage I for several years. The age of a frog may then be a factor influencing the variation in hsp70 mRNA levels between frogs if transcription is initiated at metamorphosis. The fact that stage I oocytes removed from a newly metamorphosed frog contain no detectable hsp70 transcripts (data not shown) whereas equivalent-sized oocytes from a mature frog do (Fig. 4a) supports this notion. Continued accumulation of poly $(\mathrm{A})^{+}$during vitellogenesis and variability in the duration of oogenesis have previously been suggested to explain large variations in mRNA content of fully grown oocytes (Cabada et al. 1977; Darnbrough and Ford 1979).

We have found that, contrary to previous reports, unfertilized eggs and two-cell, midblastula, and midgastrula embryos contain as much hsp 70 mRNA as stage VI oocytes that were obtained from the same frog (Fig. 4b). It would appear, therefore, that maternal hsp70 transcripts persist throughout early embryogenesis and no profound changes in stability occur during maturation or

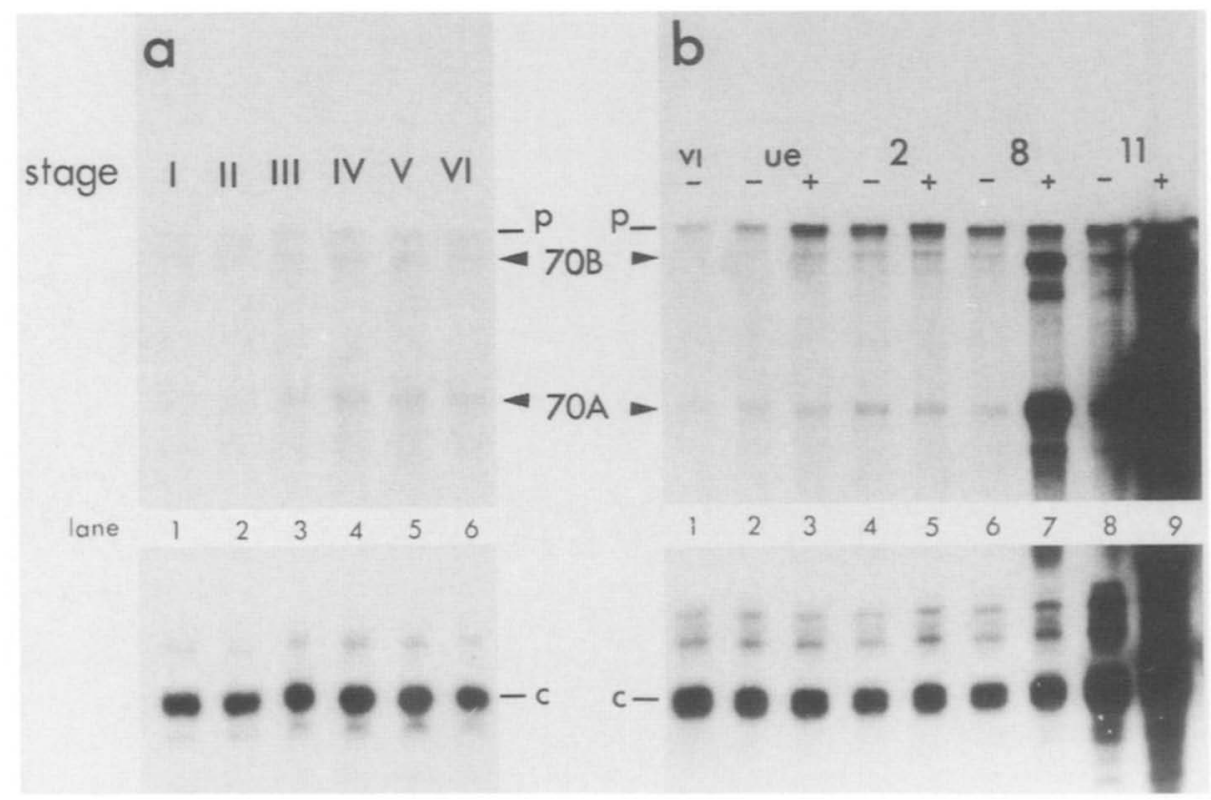

Figure 4. Oogenic accumulation and fate of hsp70 transcripts. (a) Total RNA was extracted from non-heat-shocked, nondefolliculated stage I-VI oocytes (lanes 1-6) and assayed for hsp70 transcripts by RNase protection as in Fig. 2. The upper panel shows the relative levels of hsp70A and hsp70B transcripts (indicated by arrows) at each stage. Total RNA equivalent to five oocytes $(\sim 22.5 \mu \mathrm{g}$ ) was used in each case. For comparison, the lower panel shows the relative levels of presumptive heat shock cognate transcripts $(c)$ from the same gel. Residual full-length probe is indicated (p). (b) Total RNA was extracted from stage VI oocytes (VI), unfertilized eggs (ue) and stages 2,8 , and 11 embryos $\left(2,8\right.$, and 11 , respectively) before $|-|$ and after $|+|$ a 2 -hr heat shock at $33^{\circ} \mathrm{C}$. The relative amounts of hsp70A and hsp70B transcripts were assayed as in $a$ using total RNA equivalent to five oocytes, eggs, or embryos in each case. 
fertilization. The unfertilized eggs and stage 2 embryos did not survive the 2 -hr heat shock at $33^{\circ} \mathrm{C}$. The reasons for lack of thermotolerance in eggs and early embryos therefore cannot include loss of hsp70 mRNA per se, although alterations in its translatability or capacity for translational activation remain possible. Heat-induced transcripts from embryonic genes are detectable at midblastula and their quantity is proportionately increased in relation to cell number by midgastrula (Fig. $4 \mathrm{~b}$, lanes 7 and 91.

\section{hsp 70 protein synthesis in oocytes and follicle cells}

The patterns of protein synthesis we observe in heatshocked oocytes fall into two distinct categories, which appear to correspond to the type of heat shock response described by Bienz and Gurdon (1982) and that described by Guedon et al. (1985).

In about $70 \%$ of batches of oocytes, the pattern of protein synthesis in folliculated oocytes closely resembles that described by Bienz and Gurdon (1982). Figure 5 shows representative examples of protein profiles of folliculated oocytes labeled with $\left[{ }^{35} \mathrm{~S}\right]$ methionine at $20^{\circ} \mathrm{C}$ and $35^{\circ} \mathrm{C}$ on both one-dimensional (Fig. $5 \mathrm{a}$, tracks 1 and 3 ) and two-dimensional gels (Figs. 5b, c). On heat shock the overall rate of protein synthesis falls dramatically (by up to $90 \%$, data not shown), and hsp 70 (marked $\mathrm{H}$ ) is the major protein synthesized. At $20^{\circ} \mathrm{C}$, hsp 70 synthesis is not detectable, but two other proteins of molecular weight 70,000 are made (Fig. 5b, proteins 1 and 2). Their mobilities are so similar to that of hsp 70 that it seems likely that they are the related heat shock cognates (Craig et al. 1983). Surprisingly, the translation of these two proteins appears in this experiment to be maintained at the higher temperature (Fig. 5, cf. panels b and c). However this selective translation is not always observed (Fig. 6, cf. panels $b$ and d).

To answer the question of whether any hsp70 is made in the oocytes themselves, oocytes were defolliculated after labeling (Fig. 5a, tracks 2 and 4). Clearly the follicle cells make a significant contribution to overall protein synthesis since there is less radioactive protein in the defolliculated than in the folliculated samples. Estimates based on acid precipitation of incorporated $\left.{ }^{35} S\right]$ methionine from oocyte homogenates are that the follicle cells can contribute up to about $50 \%$ of the overall protein synthesis at $20^{\circ} \mathrm{C}$, and up to $80 \%$ at $35^{\circ} \mathrm{C}$ (data not shown). Most importantly for these investigations, though, all of the labeled hsp70 protein is removed
Figure 5. Normal pattern of heat shock protein synthesis. Oocytes complete with follicle cells were incubated in medium containing $\left[{ }^{35} \mathrm{~S}\right]$ methionine for $2 \mathrm{hr}$ at $20^{\circ} \mathrm{C}$ (a, tracks 1 and 2) or at $35^{\circ} \mathrm{C}$ (tracks 3 and 4 ) and analyzed on $10 \%$ SDS-polyacrylamide gels before (tracks 1 and 3) and after (tracks 2 and 4) defolliculation. Folliculated oocytes incubated in label at $20^{\circ} \mathrm{C}(b)$ or $35^{\circ} \mathrm{C}(\mathrm{c})$ were also analyzed by two-dimensional electrophoresis. Sizes of molecular weight markers are in kilodaltons. Proteins marked 1 and 2 are discussed in the text. $(\mathrm{H}) \mathrm{hsp} 70$.

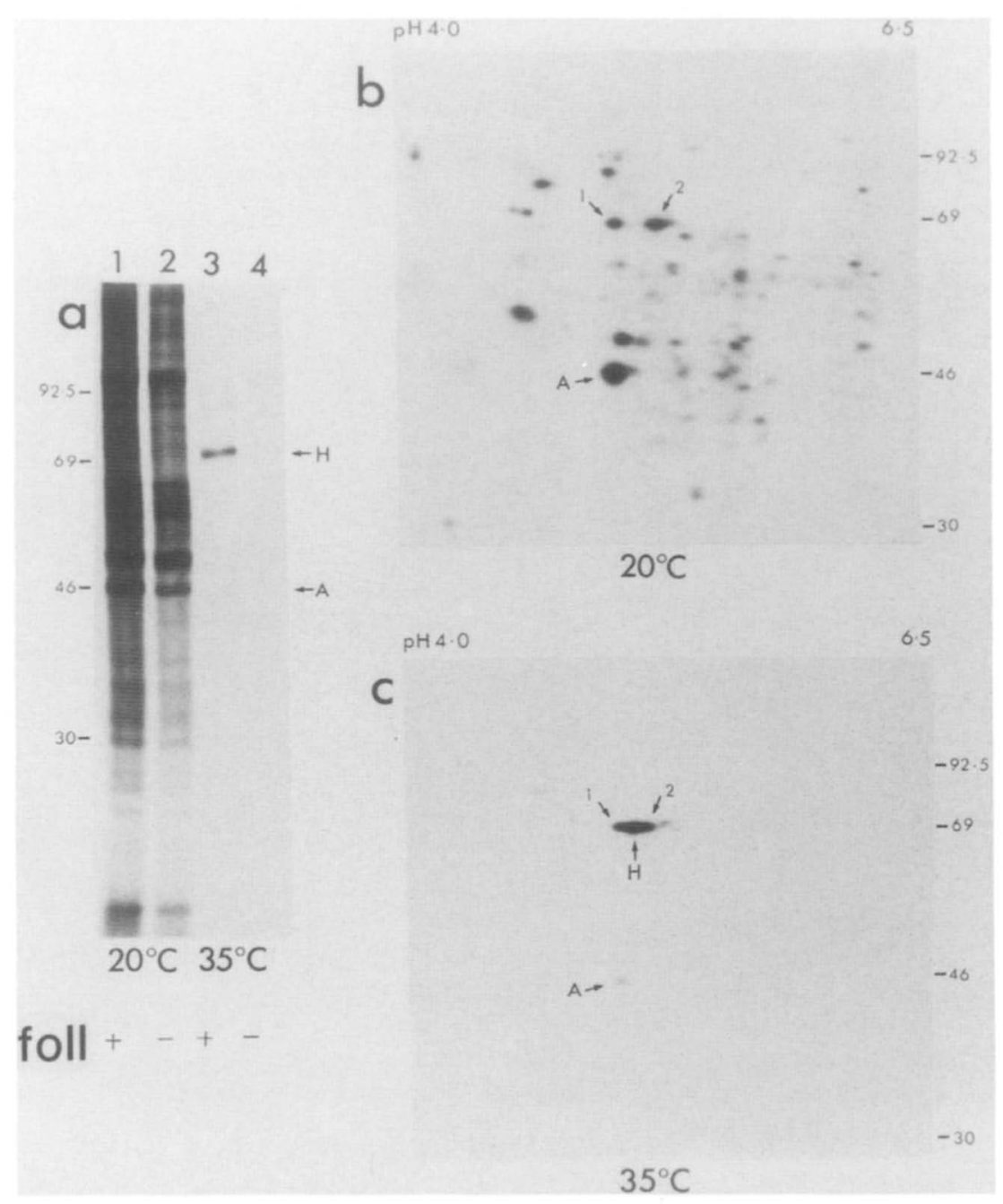


with the follicle cells (Fig. 5a, track 4). No hsp70 protein can be detected on two-dimensional gels from oocytes defolliculated after incubation at $20^{\circ} \mathrm{C}$ or $35^{\circ} \mathrm{C}$ (data not shown).

Moor and Osborn (1983) have demonstrated that the removal of follicle cells from mammalian oocytes results in a dramatic and specific reduction in actin synthesis within the oocyte, thus indicating that signals from the follicle cells can regulate protein synthesis within the oocyte. It was therefore a possibility (albeit remote) that the failure of the oocyte to translate its store of heat shock mRNA was in some way related to its intimate relationship with the surrounding follicular layer. In the experiment presented in Figure 6 we examined the effects of the removal of follicle cells prior to heat shock on the synthesis of both actin and hsp70. Clearly, although there is a generally lower incorporation of $\left[{ }^{35}\right.$ S/methionine into protein in defolliculated oocytes, there is no specific reduction in actin synthesis at $20^{\circ} \mathrm{C}$. Evidently the mammalian situation has no counterpart in amphibians. In addition, no hsp 70 synthesis can be detected in oocytes labeled after defolliculation, either at $20^{\circ} \mathrm{C}$ or $35^{\circ} \mathrm{C}$.

In about $30 \%$ of oocyte batches, the pattern of protein synthesis is completely different from that described above. There is little or no reduction in protein syn- thesis on heat shock, and several unusual proteins are found in the oocyte itself (Fig. 7a). These are generally present at $20^{\circ} \mathrm{C}$ (track 1), but are further induced by heat shock (track 2). The major bands are due to proteins of about 60,74 , and $80 \mathrm{kD}$, but there is also a band of mobility very similar to hsp70. Figure $7 \mathrm{~b}$ shows part of a two-dimensional gel of such heat-shocked, defolliculated oocytes (cf. Fig. 7a, track 2). This profile is similar to that reported by Guedon et al. (1985) in their study of the induction of the heat shock response of folliculated oocytes. The protein marked 3 is responsible for the $60-\mathrm{kD}$ band in Figure $7 \mathrm{a}$, and protein 4 is responsible for the $74-\mathrm{kD}$ band. Proteins 5 and 6 contribute to the $70-\mathrm{kD}$ band, but since they are not abundant or induced by heat shock, we believe that the major contribution on the $70-\mathrm{kD}$ region of the one-dimensional gel is from another protein of $70 \mathrm{kD}$ with an isoelectric point outside the range of this gel. Interestingly, proteins labeled 1 and 2 in Figures 5 and 6 are not detectable, as demonstrated in Figure 7c, which shows a mixture of the sample from Figure $7 \mathrm{~b}$ with one from another experiment containing follicle cell-derived hsp 70 . It is also clear from this figure that neither of the proteins 5 and 6 comigrates with bona fide hsp 70 (marked $\mathrm{H}$ ), so the 70,000 protein induced in this more unusual type of heat shock is not hsp 70 .

We cannot explain the prominence of these unusual

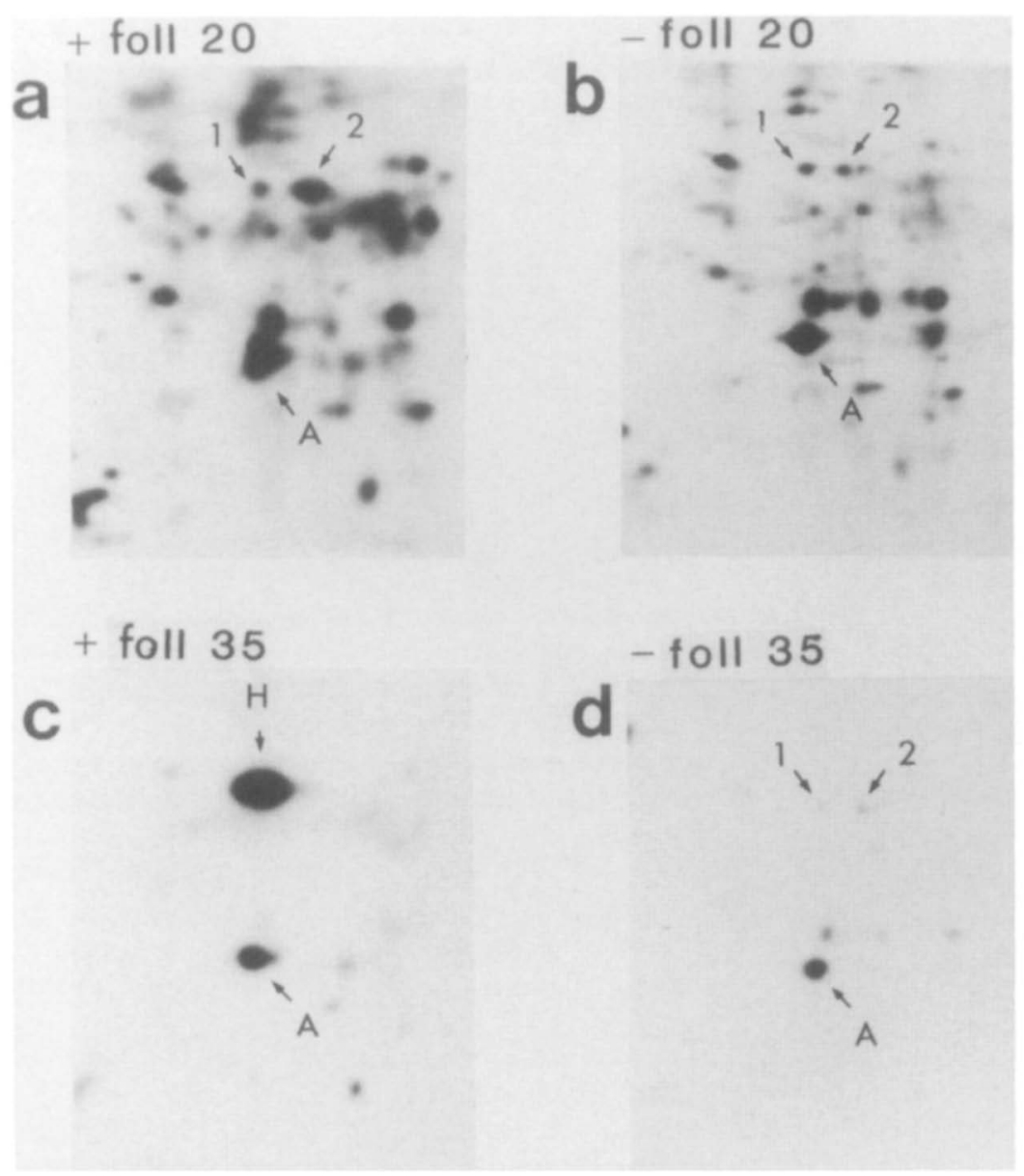

Figure 6. Two-dimensional analysis of protein synthesis in oocytes and follicle cells. Oocytes were incubated in $\left.{ }^{35} \mathrm{~S}\right]$ methionine for $2 \mathrm{hr}$ either with their follicle cells intact $(a$ and $c)$ or after defolliculation ( $b$ and $d)$. Samples $a$ and $b$ were labeled at $20^{\circ} \mathrm{C}$ and samples $c$ and $d$ at $35^{\circ} \mathrm{C}$. (H) hsp70; $(\mathrm{A})$ actin. Proteins marked 1 and 2 are discussed in the text. 
Figure 7. Abnormal pattern of heat shock protein synthesis. Oocytes were incubated in ${ }^{35} \mathrm{~S} \mid \mathrm{methio}-$ nine for $2 \mathrm{hr}$, defolliculated, and analyzed on $10 \%$ polyacrylamide gels. Track 1 shows oocytes labeled at $20^{\circ} \mathrm{C}$, and track 2 shows oocytes labeled at $35^{\circ} \mathrm{C}$. The heat-shocked, defolliculated oocytes were also analyzed on two-dimensional gels, both alone $(b)$ and mixed with a sample of oocytes containing follicle cell-derived hsp70 (c). Estimated molecular weights of proteins are expressed in kilodaltons and indicated at the right-hand figure margins; the proteins marked 1-6 are discussed in the text. $(\mathrm{H})$ hsp70; (A) actin.

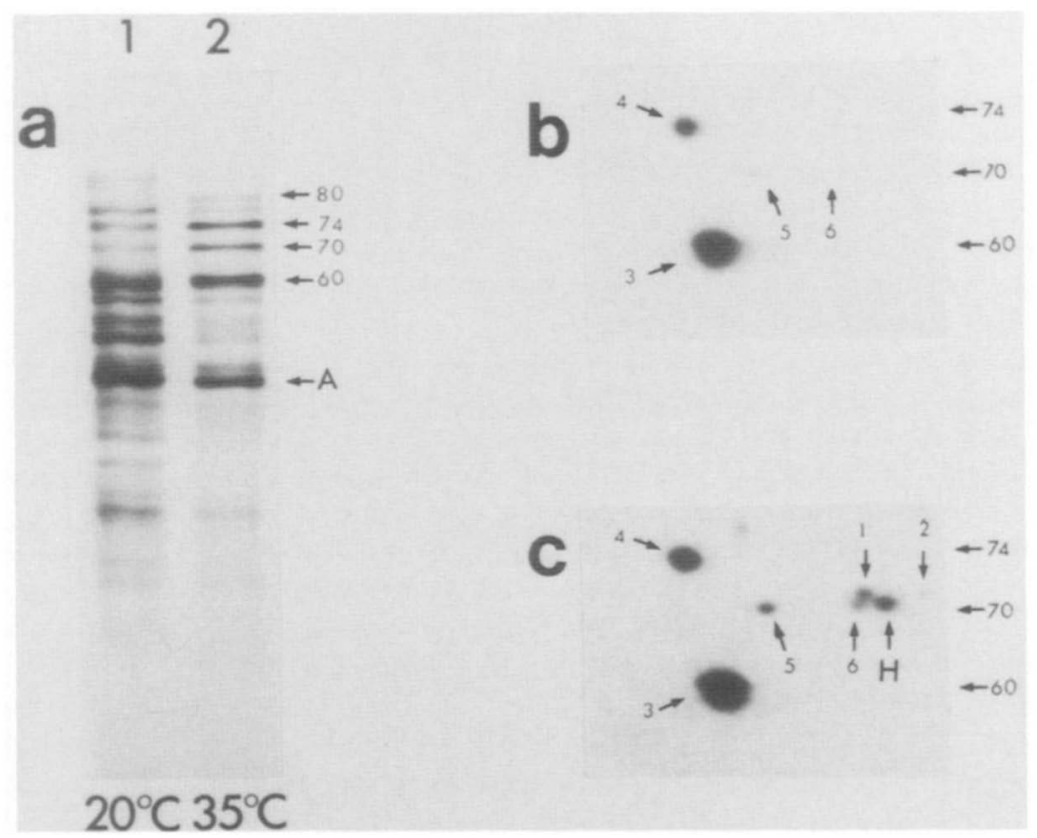

60-, 70-, 74-, and 80-kD proteins in some batches of oocytes and not in others. One possible explanation is that they are modified forms of bona fide hsp70 (for example, the $70-\mathrm{kD}$ proteins might be phosphorylated). This seems unlikely, however, since no intermediates or unmodified hsp70 are seen in defolliculated oocytes. So the most likely explanation is that they are entirely different proteins. Their expression could be due to a polymorphism in some aspect of control of the heat shock response, or it could be the response to an unidentified form of stress imposed on the frog or oocyte before the experiments were carried out. Because we rarely operate twice on the same frog, we cannot distinguish between these alternatives. The presence of these proteins does not alter our conclusion that hsp70 synthesis cannot be detected in oocytes, and emphasizes the need for two-dimensional gel analysis to distinguish bona fide hsp 70 from proteins of similar molecular weights.

A possible reason for our failure to detect translation of hsp70 mRNA in oocytes could be that the protein is synthesized at a rate below the limit of detection by our experiments. We have attempted to address this question by examining oocyte polysomes for the presence or absence of hsp70 mRNA to assess its translation status at $35^{\circ} \mathrm{C}$. Unfortunately, these experiments were inconclusive, due to the small amounts of hsp70 mRNA present. The question of translational "masking" of endogenous oocyte hsp70 transcripts therefore remains unresolved.

\section{Expression from injected hsp 70 genes}

Any mechanism controlling selective translation of oogenic hsp70 mRNA could reasonably be expected to in- volve specific sequence or structural elements within the mRNA. By reintroducing into the oocytes selectively mutated hsp70 transcripts, those regions of the mRNA that are involved could conceivably be identified. One strategy to achieve this would be to generate transcripts in vivo from injected genes. Arguably these transcripts might be regulated more appropriately than injected RNA. To test the feasibility of this approach, we have injected cloned hsp 70 genes into oocytes.

Injected hsp70A genes are efficiently transcribed by oocytes maintained at normal temperatures. Up to 3.4 ng of hsp70A mRNA is accumulated by oocytes injected wih $4 \mathrm{ng}$ of hsp70A DNA during a 24-hr incubation at $20^{\circ} \mathrm{C}$ (data not shown). Heat shock for $2 \mathrm{hr}$ at $35^{\circ} \mathrm{C}$ results in a detectable and reproducible increase in transcripts. The hsp 70 mRNA found in injected oocytes is of the same length as hsp70 mRNA induced in follicle cells by heat shock (approximately $2.6 \mathrm{~kb}$ ) and about $50 \%$ of transcripts are polyadenylated, as assessed by retention on oligo(dT)-cellulose columns (data not shown). Obviously, transcripts generated from hsp70 DNA would need to be located in the cytoplasm of the oocyte if they were to be of any use in analyzing translational control. Therefore, we investigated the accumulation and location of hsp 70 mRNA in injected oocytes. Figure 8 (lanes $1-4)$ shows that the amount of hsp70 mRNA present in Xenopus laevis oocytes incubated at $20^{\circ} \mathrm{C}$ for various times after the injection of $4 \mathrm{ng}$ of hsp70A DNA. Taking the amount of RNA present $24 \mathrm{hr}$ after injection as $100 \%$, surprisingly nearly $50 \%$ of this is produced within $2 \mathrm{hr}$ and nearly $80 \%$ by $12 \mathrm{hr}$ after injection. Eighty percent of the mRNA present ater $24 \mathrm{hr}$ at $20^{\circ} \mathrm{C}$ is present in the cytoplasm (Fig. 8, lanes 6 and 7). The $68 \%$ 
increase in transcripts induced by $2 \mathrm{hr}$ heat shock $24 \mathrm{hr}$ after injection is confined to the nucleus and therefore heat shock has no effect on the amount of hsp70 mRNA available in the cytoplasm (Fig. 8, lanes 4, 5, 8, and 9). Using this approach an increase of around 1000-fold in hsp70 mRNA content of the oocyte can be achieved, which, considering our difficulty in detecting hsp 70 protein synthesis from the endogenous RNA, allow us to investigate hsp70 translational control in oocytes.

To investigate whether oocytes are capable of making hsp70 protein if provided with more hsp $70 \mathrm{mRNA}$, we injected them with $4 \mathrm{ng} /$ oocyte of hsp70A DNA, allowed transcription to occur for $24 \mathrm{hr}$ at $20^{\circ} \mathrm{C}$, and then followed protein synthesis during a 2 -hr period at $20^{\circ} \mathrm{C}$ or $35^{\circ} \mathrm{C}$. Figure 9 shows that hsp 70 protein synthesis is easily detectable in injected oocytes that were defolliculated after labeling at $20^{\circ} \mathrm{C}$ and at $35^{\circ} \mathrm{C}$ (Fig. 9a, c). This protein comigrates with follicle cell hsp70/data not shown). In contrast, no hsp70 can be detected in uninjected defolliculated oocytes (Fig. 9b,d).

These results suggest that masking of exogenous hsp70 mRNA does not occur in Xenopus oocytes, and that hsp 70 protein can be made at $20^{\circ} \mathrm{C}$ as well as $35^{\circ} \mathrm{C}$. Drosophila hsp70 mRNA is translated efficiently in lysates of non-heat-shocked cells (Storti et al. 1980), so

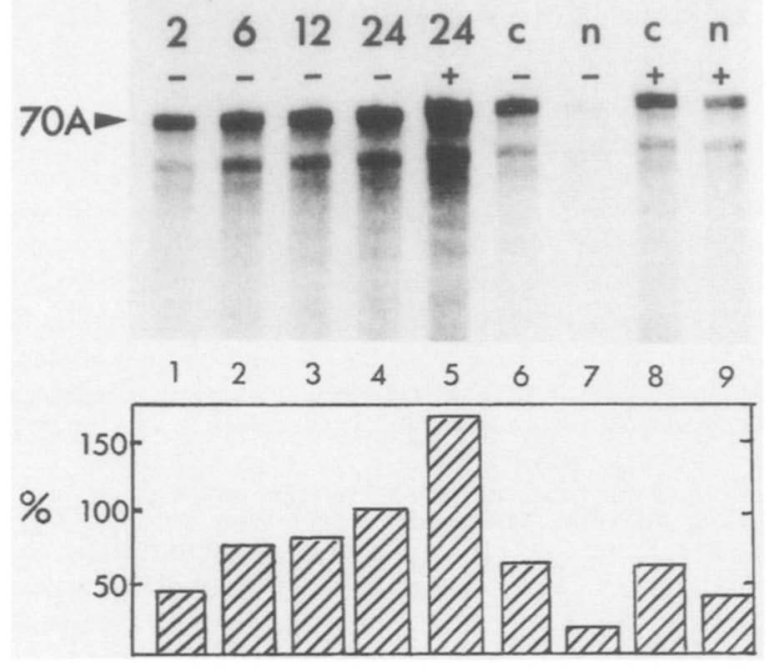

Figure 8. The accumulation and localization of transcripts from injected hsp70A genes. Oocytes were injected with $4 \mathrm{ng}$ of hsp70A DNA per oocyte. Total RNA was extracted after 2, 6, 12 , and $24 \mathrm{hr}$ at $20^{\circ} \mathrm{C}$ (lanes $1,2,3$, and 4, respectively) or after $24 \mathrm{hr}$ at $20^{\circ} \mathrm{C}$ followed by a $2-\mathrm{hr}$ heat shock at $35^{\circ} \mathrm{C}$ (lane 5 ). RNA was also extracted from the cytoplasm (c) and nuclei (n) of oocytes incubated for $24 \mathrm{hr}$ at $20^{\circ} \mathrm{C}$ (lanes 6 and 7 ) or for $24 \mathrm{hr}$ at $20^{\circ} \mathrm{C}$ followed by a $2-\mathrm{hr}$ heat shock at $35^{\circ} \mathrm{C}$ (lanes 8 and 9). The position of hsp70A transcript protected probe is indicated by the arrow. RNA equivalent to one oocyte was analyzed in each case. The lower panel indicates the relative amounts of hsp $70 \mathrm{~A}$ transcript for each sample, which were assessed by excising and counting the protected probe fragment. The level of transcripts accumulated after $24 \mathrm{hr}$ at $20^{\circ} \mathrm{C}$ (lane 4 ) was taken as $100 \%$. there is no reason to believe that if the mRNA were present in a non-heat-shocked cell it would be translated less efficiently than other mRNA molecules. However, it remains possible that endogenous hsp70 mRNA is masked in Xenopus oocytes, but the large numbers of hsp70 RNA molecules transcribed from injected genes within $24 \mathrm{hr}$ are not handled by the oocytes in the same way as the much smaller numbers of endogenous mRNA molecules made over a period of several months. The important result from this experiment is that hsp 70 mRNA transcribed from injected genes is preferentially translated at $35^{\circ} \mathrm{C}$ whereas the synthesis of other major proteins (such as actin) is barely detectable (Fig. 9c). This cannot be explained simply as a consequence of induction of transcription during heat shock, as the RNase protection data shows that the same amount of RNA is present in the cytoplasm before and during a heat shock (Fig. 8). Oocytes are therefore capable of translating hsp70 mRNA appropriately. Since it has been demonstrated that injected Drosophila hsp 70 mRNA is translated in oocytes at $20^{\circ} \mathrm{C}$ but not $35^{\circ} \mathrm{C}$ (Bienz and Pelham 1982), our results support the view that the translation of hsp 70 mRNA in frog oocytes at $35^{\circ} \mathrm{C}$ is species specific. It is therefore not surprising that there is no homology between the 5' untranslated region of the Drosophila hsp70 mRNA (Torok and Karch 1980), which contains translational control signals (McGarry and Lindquist 1985; Klemenz et al. 1985), and that of Xenopus hsp70 mRNA (Bienz 1984b).

\section{Conclusions}

Non-heat-shocked stage VI oocytes contain up to $13 \mathrm{pg}$ of hsp70A and B mRNA. These transcripts are accumulated during early oogenesis and stably retained throughout the remainder of oogenesis, maturation, ovulation, and early cleavage. No measurable increase or decrease of endogenous hsp 70 transcripts can be detected in the 24-hr period following heat shock. In contrast $70 \%$ of the hsp 70 transcripts induced in the surrounding follicle cells by heat shock disappear in the same post-heat shock period.

hsp70 protein synthesis is not detectable in completely defolliculated oocytes, either before or during heat shock. The question of translational control of endogenous hsp70 mRNA in oocytes therefore remains unresolved. Either these transcripts are not translated or they are translated at rates below the limit of detection by our analysis.

Injected hsp70A genes are transcribed efficiently by oocytes at $20^{\circ} \mathrm{C}$, leading to a rapid accumulation of nanogram quantities of hsp70A mRNA. Cytoplasmic hsp70 mRNA levels in DNA-injected oocytes are not affected by heat shock since induced transcripts remain within the nucleus during the course of the heat shock. hsp70 protein synthesis is readily detectable in hsp70 DNA-injected oocytes at both $20^{\circ} \mathrm{C}$ and $35^{\circ} \mathrm{C}$, demonstrating that (1) hsp70 mRNA can be translated by oocytes at $20^{\circ} \mathrm{C}$ and $(2)$ hsp 70 mRNA is preferentially translated at $35^{\circ} \mathrm{C}$. 


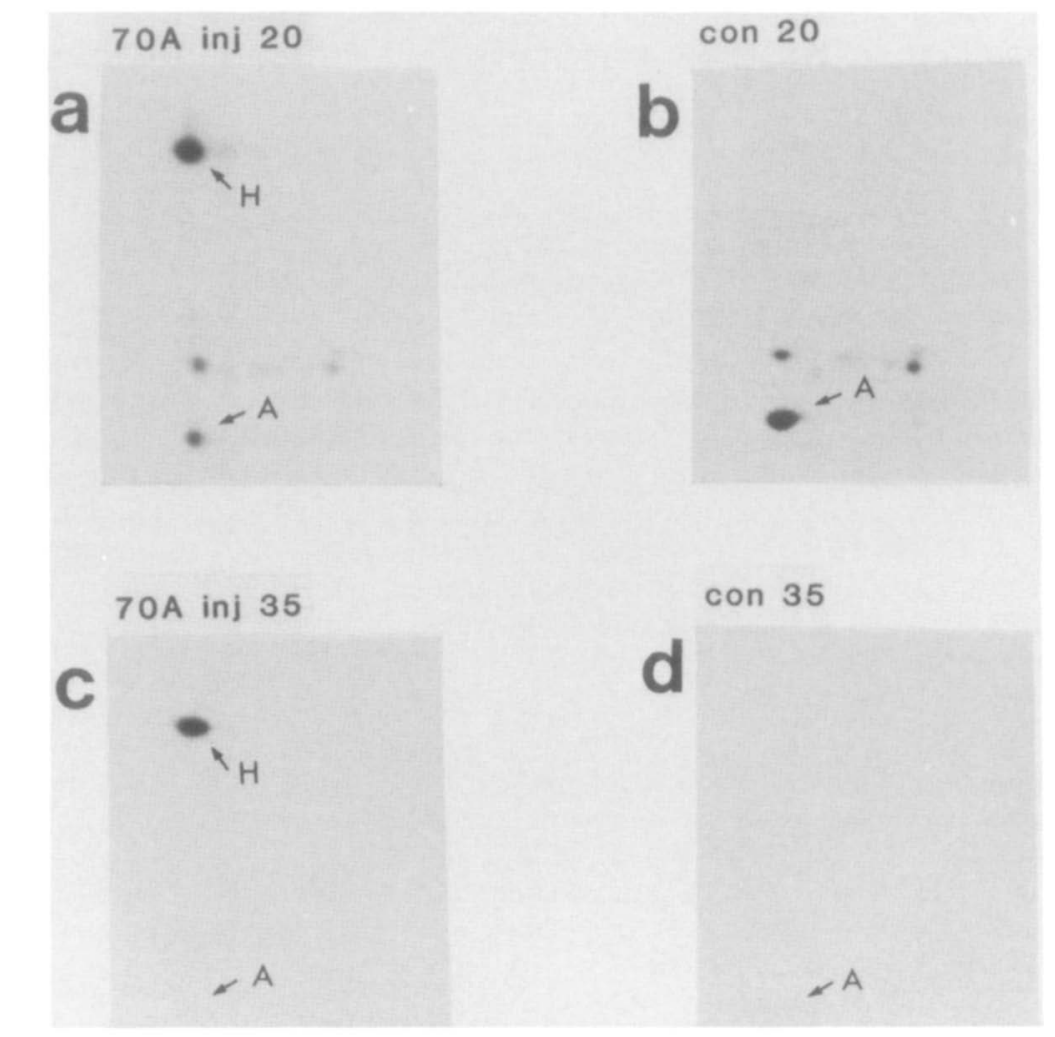

Figure 9. Expression of hsp70 protein by oocytes injected with hsp70 DNA. Oocytes were injected with $4 \mathrm{ng}$ of hsp70A DNA, incubated for $24 \mathrm{hr}$ at $20^{\circ} \mathrm{C}$, then labeled with ${ }^{35} \mathrm{~S} \mid$ methionine at $20^{\circ} \mathrm{C}(\mathrm{a})$ at $35^{\circ} \mathrm{C}(\mathrm{c})$. Uninjected control oocytes were also labeled at $20^{\circ} \mathrm{C}(b)$ or at $35^{\circ} \mathrm{C}(d)$. All oocytes were defolliculated after labeling and before two-dimensional gel analysis. (H) hsp70; (A) actin.

Although the question of translational "masking" of endogenous hsp70 mRNA remains unsettled, these results allow the design of experiments to investigate the preferential translation of hsp70 mRNA during heat shock. The heat shock response of Xenopus oocytes therefore provides a suitable system for studying this aspect of translational control.

\section{Materials and methods}

\section{Oocytes and embryos}

Oocytes were obtained from mature female frogs and maintained at $20^{\circ} \mathrm{C}$ in modified Barths' solution (MBS) as described by Colman (1984). Developmentally staged oocytes were prepared by incubating excised lobes of ovary in $2.5 \mathrm{mg} / \mathrm{ml}$ collagenase (Sigma, type IV), $88 \mathrm{mM} \mathrm{NaCl}, 1 \mathrm{mM} \mathrm{KCl}, 2.4 \mathrm{~mm}$ $\mathrm{NaHCO}_{3}, 15 \mathrm{~mm}$ Tris- $\mathrm{HCl}(\mathrm{pH} 7.35)$, at $20^{\circ} \mathrm{C}$ for $2 \mathrm{hr}$ (with gentle agitation) and manually sorting according to size and appearance (Dumont 1972). Eggs and embryos were obtained as described by Gurdon (1977) and staged according to Nieuwkoop and Faber (1967).

\section{Defolliculation of oocytes}

Oocytes were incubated in $0.25 \%$ collagenase (Sigma, type IV) in $88 \mathrm{~mm} \mathrm{NaCl}, 1.0 \mathrm{~mm} \mathrm{KCl}, 2.4 \mathrm{~mm} \mathrm{NaHCO}_{3}, 15.0 \mathrm{~mm}$ Tris$\mathrm{HCl}(\mathrm{pH} 7.6)$ at room temperature for $10 \mathrm{~min}$. The theca was then removed by manual dissection with fine watchmaker's forceps. After a further $5 \mathrm{~min}$ in collagenase, the oocytes were transferred to stripping solution $[200 \mathrm{mM} \mathrm{K}$-aspartate, $20 \mathrm{~mm}$ $\mathrm{KCl}, 1 \mathrm{~mm} \mathrm{MgCl}_{2}, 10 \mathrm{~mm}$ EGTA, 10 mM HEPES (pH 7.2); Sakmann et al. (1985)]. This separated the vitelline layer from the plasma membrane and allowed it to be removed by manual dissection. Somatic cells on the oocytes were visualized by staining in MBS containing $1 \mu \mathrm{g} / \mathrm{ml}$ Hoechst dye 33258. The number of follicle cells was estimated by photographing stained oocytes, counting the cells in a small circular area, and integrating this number over the surface area of the oocyte.

\section{RNA extraction}

Oocytes were either frozen rapidly on solid $\mathrm{CO}_{2}$ and stored at $-70^{\circ} \mathrm{C}$ or processed immediately. RNA was extracted by homogenization and incubation with SDS and proteinase $\mathrm{K}$ followed by repeated phenol extraction and precipitated with ethanol (Kressman et al. 1978). RNA was extracted in the same way from nuclei and cytoplasm separated by heating oocytes at $100^{\circ} \mathrm{C}$ for $3 \mathrm{~min}$, chilling on ice, and manual dissection (Georgiev et al. 1984). Approximately $5 \mu \mathrm{g}$ of carrier RNA was added to nuclei before extraction. Any DNA recovered together with the RNA extracted from hsp70 DNA-injected oocytes was not found to influence the RNase protection assay for hsp70 transcripts, therefore additional DNase I digestion of nucleic acid preparations was not required.

\section{DNA and sequencing}

The hsp70A and hsp70B subclones pXL10XP and pXL16P were kindly provided by Dr. Mariann Bienz. Their construction from a $X$. laevis genomic library in $\lambda 2001$ is described in Bienz (1984b). The 484-bp AhaIII-HindIII fragment from pXL16P, containing 5 '-untranslated and partial coding sequence for hsp70B, was subcloned into M13 vectors mpl8 and mpl9 and sequenced by dideoxynucleotide chain termination (Sanger et al. 1977). Comparison with the published hsp70A sequence was performed using an IBM-PC based Microgenie package (Beckman). 


\section{RNase protection assay}

The 484-bp AhaIII-HindIII fragment from pXL16P was subcloned into pGEM-1 and transcribed in vitro using SP6 RNA polymerase and $\left[\alpha^{-32}\right.$ P]UTP to produce a high-specific-activity antisense hsp70B RNA probe (Krieg and Melton 1987). Fulllength transcripts (506 nucleotides) were purified by electrophoresis and elution from $4 \%$ acrylamide, $8 \mathrm{M}$ urea gels and precipitated with ethanol. RNase protection assays were performed as described by Krieg and Melton (1987) using 4.5-22.5 $\mu \mathrm{g}$ of total RNA (equivalent to $1-5$ oocytes or embryos). Protected probe fragments were analyzed by electrophoresis on $4 \%$ acrylamide, $8 \mathrm{~m}$ urea gels $(0.4 \mathrm{~mm}$ thickness $\}$, dried, and exposed to Fuji X-ray film with a Dupont intensifying screen. The amounts of hsp70 mRNA present in each sample were estimated by including a titration of known amounts of SP6-transcribed sense hsp70 RNA in each assay. Protected probe fragments were then cut out from dried gels and counted. In all but one experiment the assay gave a linear response over a range of $0-5000 \mathrm{pg}$ of sense RNA.

\section{Labeling of oocytes and electrophoresis}

Oocytes were labeled in MBS containing $\left[{ }^{35} \mathrm{~S}\right]$ methionine at 1 $\mathrm{mCi} / \mathrm{ml}$ for $2 \mathrm{hr}$. Heat-shocked oocytes were incubated for 15 min before addition of label to allow heat shock protein synthesis to begin. If oocytes had been defolliculated before labeling, they were labeled in MBS containing 5\% dialyzed fetal calf serum. After incubation, the oocytes were washed in unlabeled MBS containing $1 \mathrm{~mm}$ methionine to prevent further incorporation of $\left[{ }^{35} S \mid\right.$ methionine during processing. They were then defolliculated if necessary, and frozen on dry ice before homogenization in $0.1 \mathrm{M} \mathrm{NaCl}, 1 \%$ Triton $\mathrm{X}-100,1 \mathrm{~mm}$ phenylmethylsulfonylfluoride (PMSF), $20 \mathrm{mM}$ Tris- $\mathrm{HCl}(\mathrm{pH} 7.6)$. Homogenates were centrifuged for $1 \mathrm{~min}$ in a minifuge to pellet the yolk platelets.

Samples were prepared for analysis on $10 \%$ SDS polyacrylamide gels (Laemmli 1970) as described by Colman (1984). Typically, one-eighth of an oocyte was loaded per lane. For two-dimensional analysis (O'Farrell, 1975), homogenates were diluted with two volumes of lysis buffer. One-third of an oocyte was loaded onto each tube gel. Second-dimension slab gels were $10 \%$ acrylamide. After electrophoresis, gels were fixed, treated with $\mathrm{En}^{3} \mathrm{Hance}$ (New England Nuclear), dried, and autoradiographed.

\section{Acknowledgment}

The authors are grateful to the British Cancer Research Campaign for support. Ann Horrell is in receipt of a Science and Engineering Research Council Studentship. We also greatly appreciate materials and advice from Dr. M. Bienz.

\section{References}

Bensaude, O., C. Babinet, M. Morange, and F. Jacob. 1983. Heat shock proteins, first major products of zygotic gene activity in mouse embryos. Nature 305: 331-333.

Bienz, M. 1984a. Developmental control of the heat shock response in Xenopus. Proc. Natl. Acad. Sci. 81: 3138-3142.

-1984b. Xenopus hsp70 genes are constitutively expressed in injected oocytes. $E M B O /$. 3: 2477-2483.

-1986. A CCAAT box confers cell-type-specific regulation on the Xenopus hsp70 gene in oocytes. Cell 46: 1037-1042.
Bienz, M. and J.B. Gurdon. 1982. The heat-shock response in Xenopus oocytes is controlled at the translational level. Cell 29: $811-819$.

Bienz, M. and H.R.B. Pelham. 1982. Expression of a Drosophila hsp in Xenopus oocytes: Conserved and divergent regulatory signals. $E M B O$ J. 1: $1583-1588$.

Cabada, M.O., C. Darnbrough, P.J. Ford, and P.C. Turner. 1977. Differential accumulation of two size classes of poly(A) associated with messenger RNA during oogenesis in Xenopus laevis. Dev. Biol. 57: 427-439.

Callen, J.C., N. Denneboug, and J.C. Mounolou. 1980. Kinetic analysis of entire oogenesis in Xenopus laevis. Dev. Growth Differ. 22: 831-840.

Colman, A. 1984. Expression of exogenous DNA in Xenopus oocytes. In Transcription and translation-A practical approach (ed. B.D. Hames and S.J. Higgins), pp. 49-69. IRL Press, Oxford.

Craig, E.A., T.D. Ingolia, and L.J. Manseau. 1983. Expression of Drosophila heat shock cognate genes during heat shock and development. Dev. Biol. 99: 418-426.

Darnbrough, C. and P.J. Ford. 1979. Turnover and processing of poly $(\mathrm{A})$ in full-grown oocytes and during progesterone-induced maturation in Xenopus laevis. Dev. Biol. 71:323340.

Di Domenico, B.J., G.E. Bugaisky, and S. Lindquist. 1982. The heat shock response is self-regulated at both the transcriptional and postranscriptional levels. Cell 31: 593-603.

Dumont, J.N. 1972. Oogenesis in Xenopus laevis. I. Stages of oocyte development in laboratory maintained animals. I. Morphol. 136: 153-180.

Georgiev, O., J. Mous, and M.L. Birnstiel. 1984. Processing and nucleocytoplasmic transport of histone gene transcripts. Nucleic Acids Res. 22: 8539.

Glover, C.V.C. 1982. Heat shock induces rapid dephosphorylation of a ribosomal protein in Drosophila. Proc. Natl. Acad. Sci. 79: $1781-1785$

Golden, L., U. Schafer, and M. Rosbach. 1980. Accumulation of individual $\mathrm{pA}^{+}$RNAs during oogenesis of Xenopus laevis. Cell 22: 835-844.

Guedon, G., D. Sovia, J.P. Ebel, N. Befort, and P. Remy. 1985. Effect of diadenosine tetraphosphate microinjection on heat shock protein synthesis in Xenopus laevis oocytes. EMBO I. 4: 3743-3749.

Gurdon, J.B. 1977. Egg cytoplasm and gene control in development. Proc. R. Soc. B. 198: 211-247.

Heikkila, J.J., M. Kloc, J. Bury, G.A. Schultz, and L.W. Browder. 1985. Acquisition of the heat-shock response and thermotolerance during early development of Xenopus laevis. Dev. Biol. 107: 483-489.

Hultmark, D., R. Klementz, and W.J. Gehring. 1986. Translational and transcriptional control elements in the untranslated leader of the heat-shock gene hsp22. Cell 44: 429-438.

King, M-L. and R. Davis. 1987. Do Xenopus oocytes have a heat shock response? Dev. Biol. 119: 532-539.

Klemenz, R., D. Hultmark, and W.J. Gehring. 1985. Selective translation of heat shock mRNA in Drosophila melanogaster depends on sequence information in the leader. EMBO I. 4: 2053-2060.

Kressman, A., S.G. Clarkson, V. Pirrotta, and M.L. Birnstiel. 1978. Transcription of cloned tRNA gene fragments, and subfragments injected into the oocyte nucleus of Xenopus laevis. Proc. Natl. Acad. Sci. 75: 1176-1180.

Krieg, P.A. and D.A. Melton. 1987. Methods Enzymol. (in press).

Kurtz, S., J. Rossi, L. Petko, and S. Lindquist. 1986. An ancient developmental induction: Heat-shock proteins induced in sporulation and oogenesis. Science 231: 1154-1157. 


\section{Horrell et al.}

Laemmli, U.K. 1970. Cleavage of structural proteins during the assembly of the head of bacteriophage T4. Nature 227: 680685.

McGarry, T.J. and S. Lindquist. 1985. The preferential translation of Drosophila hsp70 mRNA requires sequences in the untranslated leader. Cell 43: 903-911.

Moor, R.M. and J.C. Osborn. 1983. Somatic control of protein synthesis in mammalian oocytes during maturation. Ciba Fond. Symp. 98: 178-196.

Nieuwkoop, P.D. and J. Faber. 1967. Normal table of Xenopus laevis (Daudin), 2nd ed. North-Holland Publishing Company, Amsterdam.

O'Farrell, P.H. 1975. High resolution two-dimensional electrophoresis of proteins. J. Biol. Chem. 250: 4007-4021.

Parker, C.S. and J. Topol. 1984. A Drosophila RNA polymerase II transcription factor specific for the heat shock gene binds to the regulatory site of an hsp70 gene. Cell 37: 273-283.

Pelham, H.R.B. 1982. A regulatory upstream promoter element in the Drosophila hsp 70 heat-shock gene. Cell 30: 417-528. .1985. Activation of heat-shock genes in eukaryotes. Trends Genet. I: 31-35.

Riffihough, G. and H.R.B. Pelham. 1986. Activation of the Drosophila hsp27 promoter by heat-shock and by ecdysome involves independent and remote regulatory sequences. EMBO I. 5: 1653-1658.

Sakmann, B., C. Methfessel, M. Mishima, T. Takahashi, T. Takai, M. Kurasaki, K. Fukada, and S. Numa. 1985. Role of acetylcholine receptor subunits in gating of the channel. Nature 318: 538-543.

Sanger, F., S. Nickless, and A.R. Coulson. 1977. DNA sequencing with chain-terminating inhibitors. Proc. Natl. Acad. Sci. 74: 5463-5467.

Schlesinger, M.J., M. Ashburner, and A. Tissières. 1982. Heatshock from bacteria to man. Cold Spring Harbor Laboratory, Cold Spring Harbor, New York.

Storti, R.V., M.P. Scott, A. Rich, and M-L. Pardue. 1980. Translational control of protein synthesis in response to heat shock in D. melanogaster cells. Cell 22: 825-834.

Torok, I. and F. Karch. 1980. Nucleotide sequences of heat shock activated genes in Drosophila melanogaster. I. Sequences in the region of the $5^{\prime}$ and $3^{\prime}$ ends of the hsp 70 gene in the hybrid plasmid 56H8. Nucleic Acids Res. 8: 31053123 .

Wu, B.J. and R.I. Morimoto. 1986. Human hsp70 promoter contains a last two distinct regulatory domains. Proc. Natl. Acad. Sci. 83: 629-633.

Zimmerman, J.L., W. Petri, and M. Meselson. 1983. Accumulation of a specific subset of $D$. melanogaster heat shock mRNAs in normal development without heat shock. Cell 32: $1161-1170$. 


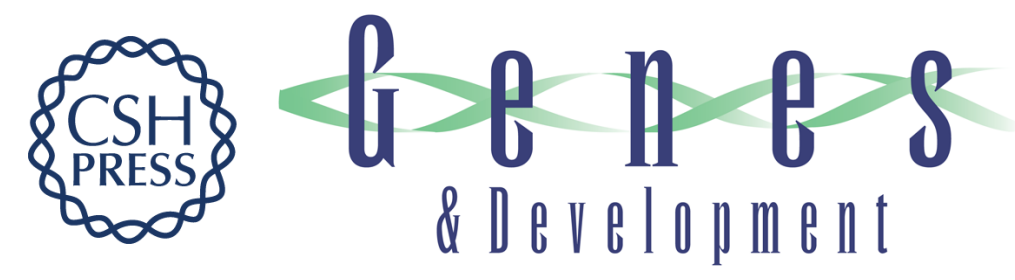

\section{Transcript levels and translational control of hsp70 synthesis in Xenopus oocytes.}

A Horrell, J Shuttleworth and A Colman

Genes Dev. 1987, 1:

Access the most recent version at doi:10.1101/gad.1.5.433

References This article cites 36 articles, 7 of which can be accessed free at: http://genesdev.cshlp.org/content/1/5/433.full.html\#ref-list-1

License

Email Alerting

Receive free email alerts when new articles cite this article - sign up in the box at Service the top right corner of the article or click here. 